\title{
Correction to: An update on extra-oral bitter taste receptors
}

Kamila Tuzim * (1) and Agnieszka Korolczuk

\section{Correction to: J Transl Med (2021) 19:440} https://doi.org/10.1186/s12967-021-03067-y

After publication of the original article [1] the authors noticed the following error:

- The author names were listed as "Tuzim Kamila and Korolczuk Agnieszka".

- The correct author names are Kamila Tuzim and Agnieszka Korolczuk.

Furthermore, several minor typos' have been corrected. The original article has been updated.
Reference

1. Tuzim K, Korolczuk A. An update on extra-oral bitter taste receptors. J Transl Med. 2021;19:440. https://doi.org/10.1186/s12967-021-03067-y.

\section{Publisher's Note}

Springer Nature remains neutral with regard to jurisdictional claims in published maps and institutional affiliations.

Published online: 26 November 2021

The original article can be found online at https://doi.org/10.1186/s12967021-03067-y.

*Correspondence: kamila.weronika.bak@gmail.com

Department of Clinical Pathomorphology, Medical University of Lublin, ul.

Jaczewskiego 8b, 20-090 Lublin, Poland original author(s) and the source, provide a link to the Creative Commons licence, and indicate if changes were made. The images or other third party material in this article are included in the article's Creative Commons licence, unless indicated otherwise in a credit line to the material. If material is not included in the article's Creative Commons licence and your intended use is not permitted by statutory regulation or exceeds the permitted use, you will need to obtain permission directly from the copyright holder. To view a copy of this licence, visit http://creativecommons.org/licenses/by/4.0/. The Creative Commons Public Domain Dedication waiver (http://creativecommons.org/publicdomain/zero/1.0/) applies to the data made available in this article, unless otherwise stated in a credit line to the data. 